\title{
Identification and enzymatic profile of yeasts isolated from artisanal cheese in Southern Brazil
}

Identificação e perfil enzimático de leveduras isoladas de queijo artesanal no sul do Brasil Melissa Fontes Landell ${ }^{1,2}$, Claudia Hartfelder ${ }^{1,3}$ \& Patrícia Valente ${ }^{1,2}$

\begin{abstract}
Yeasts may contribute positively to the characteristic taste and flavour development during cheese ripening or cause deterioration of the product. In this study we report the presence of yeasts in 59 samples of artisanal cheeses ( 43 samples of colonial cheese, 5 of ricotta, 9 of provolone, and 2 of Caccio Cavallo) marketed at stands in the coastal area of Rio Grande do Sul, collected between November 2004 and June 2005. Yeast counts were between $10^{4}$ and $10^{7} \mathrm{UFC} / \mathrm{g}$. One hundred and ten strains were isolated from 30 representative cheese samples. Of these, 97 isolates had ascomycetic affinity, and only 13 were basidiomycetes. The isolates belong to the genera Candida, Debaryomyces, Dekkera, Dipodascus, Galactomyces, Kluyveromyces, Kodamaea, Pichia, Rhodosporidium, Saccharomyces, Schizoblastosporion, Sporidiobolus, Torulaspora, Trichosporon, Yarrowia, and Zygosaccharomyces. The predominant species found were Yarrowia lipolytica, Debaryomyces hansenii, and Candida zeylanoides. More than $56 \%$ of the strains were lipolytic, while almost $13 \%$ were caseinolytic, and approximately $31 \%$ were gelatinolytic. The presence of potentially pathogenic and/or deteriorating yeasts emphasizes the need for a better hygienic control of cheese manufacturing and storage. The ability these microorganisms have to produce proteolytic and lipolytic enzymes enhance the potential risk of cheese deterioration during storage.
\end{abstract}

Key words: yeasts, cheese, enzymatic activity, protease, lipase.

\section{RESUMO}

Leveduras podem contribuir positivamente para o desenvolvimento do sabor e flavor característicos durante a maturação do queijo ou podem causar deterioração do produto. Neste estudo, nós reportamos a presença de leveduras em 59 amostras de queijo artesanal (43 amostras de queijo colonial, 5 de ricota, 9 de provolone e 2 de Caccio Cavallo) vendidas em bancas na área costeira do Rio Grande do Sul, coletadas entre novembro de 2004 e junho de 2005. A contagem de leveduras ficou entre $10^{4} \mathrm{e} 10^{7} \mathrm{CFU} / \mathrm{g}$. Cento e dez cepas foram isoladas a partir de 30 amostras representativas de queijo. Noventa e sete isolados tiveram afinidade ascomicética e apenas 13 foram basidiomicetos. Os isolados pertencem aos gêneros Candida, Debaryomyces, Dekkera, Dipodascus, Galactomyces, Kluyveromyces, Kodamaea, Pichia, Rhodosporidium, Saccharomyces, Schizoblastosporion, Sporidiobolus, Torulaspora, Trichosporon, Yarrowia e Zygosaccharomyces. As espécies predominantes encontradas foram Yarrowia lipolytica, Debaryomyces hansenii e Candida zeylanoides. Mais de 56\% das cepas foram lipolíticas, enquanto cerca de $13 \%$ foram caseinolíticas e aproximadamente $31 \%$ foram gelatinolíticas. A presença de leveduras potencialmente patogênicas e/ou deterioradoras enfatiza a necessidade de um melhor controle higiênico da manufatura e estocagem do queijo. A habilidade desses microrganismos de produzirem enzimas proteolíticas e lipolíticas aumenta o risco potencial de deterioração do queijo durante a estocagem.

Descritores: leveduras, queijo, atividade enzimática, protease, lipase. 


\section{INTRODUCTION}

The presence of yeasts in cheese is largely known, and these microorganisms may be originated from the unpasteurized milk or the environment where the cheese is manufactured, mainly the equipment and brines [11,22]. Some yeast species, as Yarrowia lipolytica and Geotrichum candidum, produce extracellular enzymes in enough amounts to modify the organoleptic characteristics of cheese and to contribute directly to its ripening $[6,12,13,25]$. Other species produce growth factors, such as amino acids and vitamins, which support the growth of other microorganisms that contribute to cheese maturation [10]. There are few reports of pathogenic yeasts associated to cheese, but Minervini et al. [16] isolated Candida albicans from a stracciatella cheese sample, and called attention to the fact that high yeast counts may represent a risk for human health. On the other hand, isolation of yeasts with potential to deteriorate cheese is relatively common, since yeasts that participate in cheese maturation can, depending on several factors, cause its deterioration [7,24].

In this study we report the diversity of yeasts in samples of artisanal cheese collected at the coastal area of Rio Grande do Sul, and their capacity of producing extracellular enzymes. Our aim is to verify the presence of potentially pathogenic and/or deteriorating yeasts in the samples in order to evaluate the impact for the consumer's health and for the shelf life of the products.

\section{MATERIALS AND METHODS}

\section{Cheese samples}

This study was accomplished with 59 samples of artisanal cheeses (43 samples of colonial cheese, 5 of ricotta, 9 of provolone, and 2 of Caccio Cavallo) marketed at stands in the coastal area of Rio Grande do Sul, collected between November 2004 and June 2005. After removal of pieces of approximately $1 \mathrm{~cm}$ thickness from the external part of each cheese, $25 \mathrm{~g}$ of each sample were added to $225 \mathrm{~mL}$ of peptone water, and homogenized in a Stomacher for 90 seconds.

\section{Isolation and identification of yeasts}

Aliquots of $0.1 \mathrm{~mL}$ from serial dilutions were spread in duplicate on acidified YM agar medium (1\% glucose, $0.3 \%$ malt extract, $0.3 \%$ yeast extract, $0.5 \%$ peptone, $2 \%$ agar, $400 \mathrm{mg} / \mathrm{L}$ of chloranphenicol, $\mathrm{pH}$ 4.0) or acidified YEPG agar medium $(0.5 \%$ yeast extract, $2 \%$ glucose, $1 \%$ peptone, $2 \%$ agar, $400 \mathrm{mg} / \mathrm{L}$ of chloranphenicol, $\mathrm{pH} 4.0$ ). After incubation at $22-25^{\circ} \mathrm{C}$ for 3-5 days, yeast colonies were counted and the results were expressed as UFC/g of cheese sample. Representative colonies of each morphological type obtained from 30 cheese samples were isolated and purified in Petri dishes containing YEPG medium. The strains were maintained in GYMP medium $(0.5 \%$ glucose, $2 \%$ malt extract, $0.5 \%$ yeast extract, $0.2 \%$ monobasic sodium phosphate, $2 \%$ agar) slants covered with a layer of sterile mineral oil, and kept in the refrigerator. The isolates were phenotypically characterized by standard tests $[3,26]$. Identification was performed according to [3] and the computer program YEASTCOMPARE [5].

\section{Enzyme assay}

For determination of lipolytic activity, the strains were previously grown on YEPG agar at $22-25^{\circ} \mathrm{C}$ for 24-48h, diluted in sterile distilled water to about $4 \times 10^{5}$ cells $/ \mathrm{mL}$, incubated for another $24 \mathrm{~h}$, and used to inoculate the solidified agar surface of the suitable medium. Lipase production medium contained $0.67 \%$ yeast nitrogen base, $2 \%$ agar, and $0.5 \%$ tween 20 (polyoxyethylene sorbitan monolaureate 20) as the sole carbon source. The strains were incubated at $22-25^{\circ} \mathrm{C}$ for 7 days and the enzymatic activity was indicated by yeast growth onto the plates. Protease production was tested by inoculation on Casein agar $(0.67 \%$ yeast nitrogen base, $0.5 \%$ glucose, $0.5 \%$ casein and $2 \%$ agar), adjusted to $\mathrm{pH} 7.0$ with $5 \mathrm{~N} \mathrm{KOH}$, and incubation at $22-$ $25^{\circ} \mathrm{C}$ for 7 days. After precipitation with $1 \mathrm{M} \mathrm{HCl}$, protease production was indicated by the presence of a clear zone around the colonies [19]. The hydrolysis of gelatin was also used to verify the protease production. Yeasts were inoculated in tubes containing maltgelatin (10\% extract of malt and $12 \%$ gelatin), and incubated of $22-25^{\circ} \mathrm{C}$ for 21 days. Protease activity was verified through the hydrolysis of the gelatin, and consequent liquefaction of the medium [1].

\section{RESULTS}

Yeast counts were between $10^{4}$ and $10^{7} \mathrm{UFC} / \mathrm{g}$ (data not shown). One hundred and ten strains were isolated from 30 samples of colonial, provolone, ricotta and Caccio Cavallo cheese. Of these, 97 isolates had ascomycetic affinity, and only 13 were basidiomycetes. The identified isolates belong to the genera Candida, Debaryomyces, Dekkera, Dipodascus, Galactomyces, Kluyveromyces, Kodamaea, Pichia, Rhodosporidium, Saccharomyces, Schizoblastosporion, Sporidiobolus, Torulaspora, Trichosporon, Yarrowia, and Zygosaccharomyces (Table 1). The lipolytic and 
proteolytic profile of the strains can be found on Table 2. More than $56 \%$ of the strains were lipolytic. Proteolytic capacity was verified through production of caseinase and gelatinase. Almost 13\% of the strains were caseinolytic, while approximately $31 \%$ were gelatinolytic.

\section{DISCUSSION}

Several authors have reported a broad range of yeast numbers $\left(10^{1}\right.$ to $\left.10^{9} \mathrm{UFC} / \mathrm{g}\right)$ in cheese, depending on the cheese type and producer $[2,8,23]$. In Brazil, Souza et al. [18], studying the serrano cheese produced in Rio Grande do Sul, found yeast counts between $10^{3}$ and $10^{6}$

Table 1. Frequencies of yeasts isolated from 30 artisanal cheese samples from the coastal area of Rio Grande do Sul, collected between November 2004 and June 2005.

\begin{tabular}{|c|c|c|c|c|c|}
\hline \multirow[b]{2}{*}{ Yeasts } & \multirow{2}{*}{$\begin{array}{c}\text { Total } \\
\text { number of } \\
\text { isolates }\end{array}$} & \multicolumn{4}{|c|}{ Number of isolates per cheese type } \\
\hline & & $\begin{array}{c}\begin{array}{c}\text { Colonial cheese } \\
n=20\end{array} \\
\text { c }\end{array}$ & $\begin{array}{c}\text { Ricotta } \\
n=4\end{array}$ & $\begin{array}{c}\text { Provolone } \\
n=4\end{array}$ & $\begin{array}{c}\text { Caccio cavallo } \\
n=2\end{array}$ \\
\hline Candida catenulata & 3 & 3 & - & - & - \\
\hline Candida haemulonii-like & 1 & - & - & 1 & - \\
\hline Candida intermedia & 1 & - & 1 & - & - \\
\hline Candida lusitaniae & 4 & 4 & - & - & - \\
\hline Candida maltosa & 2 & 2 & - & - & - \\
\hline Candida maltosa-like & 1 & 1 & - & - & - \\
\hline Candida parapsilosis & 2 & - & 1 & 1 & - \\
\hline Candida pseudogloebosa & 1 & 1 & - & - & - \\
\hline Candida restingae & 1 & 1 & - & - & - \\
\hline Candida rugosa & 3 & 2 & - & 1 & - \\
\hline Candida sake & 3 & 2 & 1 & - & - \\
\hline Candida sake-like & 1 & 1 & - & - & - \\
\hline Candida sorbophila-like & 1 & 1 & - & - & - \\
\hline Candida vinaria-like & 2 & 1 & 1 & - & - \\
\hline Candida zeylanoides & 9 & 7 & 1 & - & 1 \\
\hline Candida zeylanoides-like & 1 & - & 1 & - & - \\
\hline Candida spp. & 7 & 3 & 3 & 1 & - \\
\hline Debaryomyces hansenii & 11 & 6 & 2 & 2 & 1 \\
\hline Debaryomyces maramus & 1 & 1 & - & - & - \\
\hline Dekkera anomala & 1 & 1 & - & - & - \\
\hline Dekkera bruxelensis & 1 & 1 & - & - & - \\
\hline Dipodascus sp. & 1 & 1 & - & - & - \\
\hline Galactomyces geotrichum & 3 & 3 & - & - & - \\
\hline Kluyveromyces lactis & 6 & 5 & 1 & - & - \\
\hline Kluyveromyces marxianus & 3 & 2 & - & 1 & - \\
\hline Kodamaea ohmeri & 1 & - & 1 & - & - \\
\hline Pichia guilliermondii & 1 & 1 & - & - & - \\
\hline Pichia rabaulensis-like & 1 & 1 & - & - & - \\
\hline Pichia scolyti? & 1 & 1 & - & - & - \\
\hline Rhodosporidium toruloides & 3 & 1 & 2 & - & - \\
\hline
\end{tabular}


Table 1. (cont.)

\begin{tabular}{|c|c|c|c|c|c|}
\hline \multirow{2}{*}{ Yeasts } & \multirow{2}{*}{$\begin{array}{c}\text { Total number } \\
\text { of isolates }\end{array}$} & \multicolumn{4}{|c|}{ Number of isolates per cheese type } \\
\hline & & $\begin{array}{c}\begin{array}{c}\text { Colonial cheese } \\
n=20\end{array} \\
\text { c }\end{array}$ & $\begin{array}{c}\text { Ricotta } \\
n=4\end{array}$ & $\begin{array}{c}\text { Provolone } \\
n=4\end{array}$ & $\begin{array}{c}\text { Caccio cavallo } \\
n=2\end{array}$ \\
\hline Saccharomyces cerevisiae & 2 & 2 & - & - & - \\
\hline Saccharomyces unisporus & 1 & 1 & - & - & - \\
\hline Saccharomycopsis crataegensis & 1 & 1 & - & - & - \\
\hline Schizoblastosporion starkeyi-henricii & 1 & - & - & 1 & - \\
\hline Schizoblastosporion sp. & 1 & - & - & 1 & - \\
\hline Sporidiobolus pararoseus & 1 & - & - & 1 & - \\
\hline Torulaspora delbrueckii & 1 & - & - & - & 1 \\
\hline Trichosporon inkin & 4 & 2 & 1 & 1 & - \\
\hline Trichosporon loubieri & 4 & 3 & - & 1 & - \\
\hline Trichosporon ovoides & 1 & 1 & - & - & - \\
\hline Yarrowia lipolytica & 15 & 11 & 2 & 1 & 1 \\
\hline Zygosaccharomyces bisporus & 1 & 1 & - & - & - \\
\hline
\end{tabular}

Table 2. Production of proteases (caseinase and gelatinase) and lipase by yeasts isolated from 30 artisanal cheese samples from the coastal area of Rio Grande do Sul, collected between November 2004 and June 2005.

\begin{tabular}{lccc}
\hline Species & Caseinase & Gelatinase & Lipase \\
\hline Candida catenulata & $1^{\text {a }}$ & 2 & 2 \\
Candida haemulonii-like & - b & - & 1 \\
Candida intermedia & - & - & 1 \\
Candida lusitaniae & - & - & 2 \\
Candida maltosa & - & 2 & - \\
Candida maltosa-like & - & 1 & 1 \\
Candida parapsilosis & - & - & - \\
Candida pseudogloebosa & - & - & 1 \\
Candida restingae & - & - & 1 \\
Candida rugosa & - & - & 1 \\
Candida sake & - & - & 1 \\
\hline Candida sake-like & - & - & 1 \\
\hline
\end{tabular}

UFC/g, while Feitosa et al. [9] reported yeast counts between $10^{4}$ and $10^{8} \mathrm{UFC} / \mathrm{g}$ in coalho and butter cheese from Rio Grande do Norte, and Borelli [4] found $10^{2}$ to $10^{7}$ $\mathrm{UFC} / \mathrm{g}$ in the curd and Canastra cheese artisanally produced in Minas Gerais. We have found yeast counts between $10^{4}$ and $10^{7} \mathrm{UFC} / \mathrm{g}$, a range that is very similar to those reported by other authors. Thirty nine out of 43 colonial cheese samples had counts over $10^{5} \mathrm{UFC} / \mathrm{g}$, including 27 samples with counts over $10^{6} \mathrm{UFC} / \mathrm{g}$ (data not shown). There is a concern about this high count because yeast numbers higher than $10^{6}-10^{7} \mathrm{UFC} / \mathrm{g}$ can deteriorate the product [10]. Distribution of yeast counts within the $10^{4}$ to $10^{7} \mathrm{UFC} / \mathrm{g}$ range was even for the other cheese sampled.

The predominant species found in the analyzed cheese samples were Yarrowia lipolytica, Debaryomyces hansenii, and Candida zeylanoides, although $C$. zeylanoides was not isolated from provolone cheese, probably due to the small sample size. These 
species are commonly isolated from cheese and other food items $[2,4,8,17]$. Y. lipolytica has already been proven to produce enough extracellular enzymes to modify the organoleptic characteristics of cheese during its maturation $[6,12,13,25]$. D. hansenii is commonly associated with cheese manufacturing, and its presence is probably due to its high salt tolerance, among other factors [21]. The high frequency of $C$. zeylanoides, which is often associated to food deterioration, may be an

\begin{tabular}{|c|c|c|c|}
\hline Species & Caseinase & Gelatinase & Lipase \\
\hline Candida sorbophila-like & - & - & - \\
\hline Candida vinaria-like & - & 1 & 1 \\
\hline Candida zeylanoides & 1 & - & 4 \\
\hline Candida zeylanoides-like & - & - & - \\
\hline Candida spp. & 1 & 3 & 5 \\
\hline Debaryomyces hansenii & - & - & 4 \\
\hline Debaryomyces maramus & - & - & 1 \\
\hline Dekkera anomala & - & - & - \\
\hline Dekkera bruxelensis & - & - & 1 \\
\hline Dipodascus sp. & - & 1 & 1 \\
\hline Galactomyces geotrichum & - & 3 & - \\
\hline Kluyveromyces lactis & - & - & 2 \\
\hline Kluyveromyces marxianus & - & - & 1 \\
\hline Kodamaea ohmeri & - & - & - \\
\hline Pichia guilliermondii & - & - & 1 \\
\hline Pichia rabaulensis-like & - & - & 1 \\
\hline Pichia scolyti? & - & 1 & 1 \\
\hline Rhodosporidium toruloides & 1 & - & 3 \\
\hline Saccharomyces cerevisiae & - & - & 1 \\
\hline Saccharomyces unisporus & - & - & - \\
\hline Saccharomycopsis crataegensis & - & 1 & 1 \\
\hline Schizoblastosporion starkeyi-henricii & - & - & - \\
\hline Schizoblastosporion sp. & 1 & 1 & - \\
\hline Sporidiobolus pararoseus & - & - & 1 \\
\hline Torulaspora delbrueckii & 1 & - & - \\
\hline Trichosporon inkin & - & 2 & 3 \\
\hline Trichosporon loubieri & - & 1 & 3 \\
\hline Trichosporon ovoides & - & - & 1 \\
\hline Yarrowia lipolytica & 4 & 13 & 11 \\
\hline Zygosaccharomyces bisporus & - & - & - \\
\hline
\end{tabular}

indicative of the poor sanitary conditions these artisanal cheese are being produced and stored prior to sale.

Trichosporon inkin was found in three cheese types. T. inkin belongs to a group of potentially pathogenic yeasts commonly isolated from cheese and cheese factories. Apart from T. inkin, other clinically relevant yeasts have been isolated, although in low numbers. Candida lusitaniae was found in four and Pichia guilliermondii in one out of 20 samples of colonial cheese, and Candida parapsilosis in one out of four samples each of provolone and ricotta cheese. The isolation of these clinically relevant yeasts may reflect the poor hygienic conditions the cheeses are produced, and the fact that these yeasts are capable of surviving the conditions of cheese manufacturing. They are also commonly found in raw milk [15]. So, it is probable that their source is the milk used for manufacturing the cheese. Trichosporon loubieri and Trichosporon ovoides were also isolated from few samples of colonial and/or provolone cheese. T. loubieri has been isolated from dairies, cow with mastitis and mastitic milk [3], and its source is probably also the milk used to produce cheese. T. ovoides is associated with cases of white piedra and skin [3], and is a probable contaminant from human origin, emphasizing the poor hygienic conditions of cheese production and storage.

The isolation of yeasts with potential to deteriorate cheese is very common. Fadda et al. [7] reported the association of altered packages of feta cheese with Dekkera anomala. This species is capable of a strong fermentation of lactose, producing gas and altering the package. We have found $D$. anomala and Dekkera bruxelensis in samples of colonial cheese, but they do not seem to be common. We have isolated Torulaspora delbrueckii from one out of two samples of Caccio Cavallo cheese. As this yeast is also considered a potentially deteriorating microorganism, this isolation may be of concern.

Few strains with basidiomycetic affinity other than Trichosporon were found. Rhodosporidium toruloides was isolated from one sample of colonial cheese and two of ricotta, while Sporidiobolus pararoseus 
was found in one sample of provolone cheese. This low frequency of basidiomycetic yeasts may mean that they are not common inhabitants of cheese samples, but instead they are probably airborne contaminants.

Colonial and ricotta cheese can be considered moisty, while provolone and Caccio Cavallo are dry cheese. Although the differences in sample size among the analyzed cheese can limit the conclusions, it is worth noting that Candida haemulonii-like, Schizoblastosporium starkeyi-henricii, Schizoblastosporium sp. and $S$. pararoseus were only found in dry cheese in spite of the low sample number (6 samples). At present, it is not possible to infer if the three former species are airborne contaminants as it is believed for $S$. pararoseus. Moisty cheese are more represented in our samples (20 samples of colonial and 4 of ricotta). The isolation of a species from only colonial cheese is not very informative, as it can be biased by the sample number, but isolation from both colonial and ricotta of a species not present in dry cheeses may be meaningful. It is the case of $K$. lactis, Candida vinaria-like and $R$. toruloides. The latter two species were found in few samples, and can represent eventual contaminants, but isolation of $K$. lactis only from moisty cheese is noteworthy. $K$. lactis is a species commonly isolated from cheese, and its presence in dairy products is usually explained by its ability to assimilate and ferment the lactose present in milk [8]. It would be interesting to test if this species is able to survive and reproduce in the harsh conditions of dry cheese.

Most of the reports in the literature deal with proteolytic and lipolytic activities of few selected strains isolated from cheese, thus preventing comparisons with our results. The low percentage of proteolytic strains in our samples may reflect the fact that protease production was tested only in neutral conditions. $\mathrm{pH}$ variations during protease production may influence the results [20], so it would be interesting to perform the tests also in more acidic conditions. Strains were more gelatinolytic than caseinolytic. As casein is the main milk protein, it seems that the proteolytic capacity of the isolates has a low influence over cheese protein content. More than $56 \%$ of our isolates were lipolytic, although some of them were weak lipase producers (data not shown). Borelli [4] found only 3.2\% of lipolytic strains in Canastra cheese in Minas Gerais. This discrepancy is probably due to the methodology these authors employed for verifying lipolytic activity, since they used tributyrin instead of tween 20 as the substrate for lipase production. Differences in the substrate used in lipase assays may detect enzymes with different specificities [14], explaining these results.

\section{CONCLUSION}

In summary, the presence of potentially pathogenic and/or deteriorating yeasts in cheese samples collected in the coastal area of Rio Grande do Sul emphasizes the need for a better hygienic control of cheese manufacturing and storage. The ability these microorganisms have to produce proteolytic and lipolytic enzymes enhance the potential risk of cheese deterioration during storage.

Acknowledgements. The authors thank Dr. Marisa da Costa and Cristina Zaffari (Msc.) for kindly providing the cheese samples. This work was supported by PROPESQ/UFRGS (financial support $n^{\circ}$ 237). M.F. Landell and C.C. Hartfelder received fellowships from CNPq and FAPERGS, respectively.

\section{REFERENCES}

1 Abranches J., Morais P.B., Rosa C.A., Mendonça-Hagler L.C. \& Hagler A.N. 1997. The incidence of killer activity and extracellular proteases in tropical yeast communities. Canadian Journal of Microbiology. 43: 328-336.

2 Addis E., Fleet G.H., Cox J.M., Kolak D. \& Leung T. 2001. The growth, properties and interactions of yeasts and bacteria associated with the maturation of Camembert and blue-veined cheeses. International Journal of Food Microbiology. 69: 25-36.

3 Barnett J.A., Payne R.W. \&. Yarrow. D. 2000. Yeasts: characteristics and identification. 3rd edn. Cambridge: Cambridge University Press, 1139p.

4 Borelli B.M. 2002. Quantificação dos indicadores higiênico-sanitários e da diversidade de leveduras durante a fabricação do queijo minas curado produzido na Serra da Canastra, MG. Minas Gerais, MG. Dissertação (Mestrado em Ciências Biológicas Microbiologia) - Programa de Pós-graduação em Ciências Biológicas - Microbiologia, Universidade Federal de Minas Gerais.

5 Cirielo C.J. \& Lachance M.A. 2001. YEASTCOMPARE. University of Western Ontario, London, ON. Copyright ® 1999-2001.

6 Cosentino S., Fadda M.E., Deplano M., Mulargia A.F. \& Palmas F. 2001. Yeasts associated with Sardinian ewe's dairy products. International Journal of Food Microbiology. 69: 53-58. 
7 Fadda M.E., Cosentino S., Deplano M. \& Palmas F. 2001. Yeast populations in sardinian feta cheese. International Journal of Food Microbiology. 69: 153-156.

8 Fadda M.E., Mossa V., Pisano M.B., Deplano M. \& Cosentino S. 2004. Occurrence and characterization of yeasts isolated from artisanal Fiore Sardo cheese. International Journal of Food Microbiology. 95: 51-59.

9 Feitosa T., Borges M.F., Nassu R.T., de Azevedo E.H.F. \& Muniz C.R. 2003. Pesquisa de Salmonella sp., Listeria sp. e microrganismos indicadores higiênico-sanitários em queijos produzidos no estado do Rio Grande do Norte. Ciência e Tecnologia de Alimentos. 23(suppl): 162-165.

10 Fleet G.H. 1990. Yeasts in dairy products. Journal of Applied Bacteriology. 68: 199-211.

11 Fleet G.H. \& Mian M.A. 1987. The occurrence and growth of yeasts in dairy products. International Journal of Food Microbiology. 4: 145-155.

12 Freitas A.C., Pintado A.E., Pintado M.E. \& Malcata F.X. 1999. Role of dominant microflora of Picante cheese on proteolysis and lipolysis. International Dairy Journal. 9: 593-603.

13 Gaborit P., Menard A. \& Morgan F. 2001. Impact of ripening strains on the typical flavour of goat cheeses. International Dairy Journal. 11: 315-325.

14 Gandolfi R., Martinelli F., Lazzarini A. \& Molinari F. 2000. Cell-bound and extracellular carboxylesterases from Streptomyces: hydrolytic and synthetic activities. Journal of Applied Microbiology. 89: 870-875.

15 Lagneau P.E., Lebtahi K. \& Swinne D.1996. Isolation of yeasts from bovine milk in Belgium. Mycopathologia. 135: 99-102.

16 Minervini F., Montagna,M.T., Spilotros G., Monace L., Santacroce M.P. \& Visconti A. 2001. Survey on mycoflora of cow and buffalo dairy products form southern Italy. International Journal of Food Microbiology. 69: 141-146.

17 Pereira-Diaz S., Potes M.E., Marinho A., Malfeito-Ferreira M. \& Loureiro V. 2000. Characterisation of yeast flora isolated from an artisanal Portuguese ewe's cheese. International Journal of Food Microbiology. 60: 55-63.

18 Souza C.F.V., Rosa T.D. \& Ayub M.A.Z. 2003. Changes in the microbiological and physicochemical characteristics of Serrano cheese during manufacture and ripening. Brazilian Journal of Microbiology. 34: 260-266.

19 Strauss M.L.A, Jolly N.P, Lambrechts M.G \& Rensburg P. Van. 2001. Screening for the production of extracellular hydrolytic enzymes by non-Saccharomyces wine yeasts. Journal of Applied Microbiology. 91: 182-190.

20 Trindade R.C., Resende M.A., Silva C.M. \& Rosa C.A. 2002. Yeasts associated with fresh and frozen pulps of Brazilian tropical fruits. Systematic and Applied Microbiology. 25: 294-300.

21 Valdés-Stauber N., Sherer S. \& Seiler H. 1997. Identification of yeasts and coryneform bacteria from the surface microflora of brick cheeses. Food Microbiology. 34: 115-129.

22 Viljoen B.C. \& Greyling T. 1995. Yeasts associated with Cheddar and Gouda making. International Journal of Food Microbiology. 28: 79-88.

23 Welthagen J.J. \& Viljoen B.C.. 1998. Yeast profile in Gouda cheese during processing and ripening. International Journal of Food Microbiology. 41: 185-194.

24 Westall, S. \& Filtenborg O. 1998. Yeast occurrence in Danish feta cheese. Food Microbiology. 15: $215-222$.

25 Wyder M.T. \& Puhan Z. 1999. Role of selected yeasts in cheese ripening: an evaluation in aseptic cheese curd slurries. International Dairy Journal. 9: 117-124.

26 Yarrow D. 1998. Methods for the isolation, maintenance, and identification of yeasts. In: Kurtzman C.P. \& Fell J.W (Eds). The Yeasts. A Taxonomic Study. Amsterdam: Elsevier Science, pp.77-100.

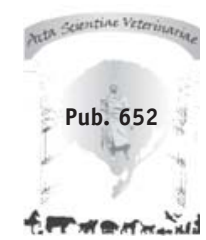

